\title{
Finance and the Sources of Growth
}

\author{
Thorsten Beck, Ross Levine, and Norman Loayza
}

Beck: University of Virginia and World Bank; Levine: University of Virginia; Loayza: Banco Central de Chile. This paper's findings, interpretations, and conclusions are entirely those of the authors and do not necessarily represent the views of the Banco Central de Chile, World Bank, its Executive Directors, or the countries they represent. 


\section{Introduction}

Joseph Schumpeter argued in 1911 that banks play a pivotal role in economic development because they choose which firms get to use society's savings. According to this view, the banking sector alters the path of economic progress by affecting the allocation of savings and not necessarily by altering the saving rate. Thus, the Schumpeterian view of finance and development highlights the impact of banks on productivity growth and technological change. ${ }^{1}$ Alternatively, a vast development economics literature argues that capital accumulation is the key factor underlying economic growth. ${ }^{2}$ According to this view, better banks influence growth primarily by raising domestic saving rates and attracting foreign capital. Our paper empirically assesses the impact of banks on productivity growth, capital accumulation, private saving rates, and overall growth.

This paper is further motivated by a rejuvenated movement in macroeconomics to understand cross-country differences in both the level and growth rate of total factor productivity. A long empirical literature successfully shows that "something else" besides physical and human capital accounts for the bulk of cross-country differences in both the level and growth rate of real per capita Gross Domestic Product (GDP). Nevertheless, economists have been relatively unsuccessful at fully characterizing this residual, which is generally termed "total factor productivity." Recent papers by Hall and Jones (1998), Harberger (1998), Klenow (1998), and Prescott (1998) have again focused the profession's attention on the need for improved theories of total factor productivity growth. While we do not advance a new theory, this paper empirically explores one cause of cross-country differences in total factor productivity growth: differences in the level of banking sector development.

\footnotetext{
${ }^{1}$ Recent theoretical models have carefully documented the links between banks and economic activity. By economizing on the costs of acquiring and processing information about firms and managers, banks can influence resource allocation. Better banks are lower cost producers of information with consequent ramifications for capital allocation and productivity growth [Diamond 1984; Boyd and Prescott 1986; Williamson 1987; Greenwood and Jovanovic 1990; and King and Levine 1993b].
} 
Specifically, this paper examines whether the level of banking sector development exerts a causal impact on real per capita GDP growth, capital per capita growth, productivity per capita growth and private saving rates. For convenience, we refer to capital per capita growth, productivity per capita growth and private saving as the "sources of economic growth." Recent industry- and firm-level research suggests that the level of banking sector development has a large, causal impact on real per capita GDP growth [Rajan and Zingales 1998; Demirgüç-Kunt and Maksimovic 1999]. ${ }^{3}$ Past work, however, does not explore the channels via which banks affect economic growth. Thus, using a crosscountry dataset, we assess the causal impact of banks on capital accumulation, private saving rates and productivity growth and trace these effects through to overall per capita GDP growth.

This paper improves on the existing literature both in terms of econometric technique and data. First, while King and Levine (1993a) and Levine and Zervos (1998) empirically assess the connection between banking sector development and the sources of economic growth, they do not explicitly confront the issue of causality. We use two econometric techniques to control for the simultaneity bias that may arise from the joint determination of banking sector development and (i) capital accumulation, (ii) total factor productivity growth, and (iii) private saving rates. The first technique employs a pure cross-sectional, instrumental variable estimator, where data for 63 countries are averaged over the period 1960-95. The dependent variable is either real per capita GDP growth, real per capita capital stock growth, productivity growth, or private saving rates. Besides a measure of banking sector development, the regressors include a wide array of conditioning information to control for other factors associated with economic development. To control for simultaneity bias, we use the legal origin of each country as an instrumental variable to extract the exogenous component of banking sector development. Legal scholars note that many countries can be divided into countries with English,

\footnotetext{
${ }^{2}$ See discussion and citations in King and Levine (1994), Easterly (1998), and Easterly, Levine, and Pritchett (1999).
} 
French, German, or Scandinavian legal origins and those countries typically obtained their legal systems through occupation or colonization. Thus, we take legal origin as exogenous. Moreover, LaPorta, Lopez-de-Silanes, Shleifer, and Vishny (1997, 1998; henceforth LLSV) show that legal origin substantively affected (a) laws concerning bank credits, (b) systems for enforcing bank contracts, and (c) standards for corporate information disclosure. Each of these features of the contracting environment helps explain cross-country differences in banking sector development [Levine, Loayza, and Beck 1998; Levine 1998, 1999]. Thus, after extending the LLSV data on legal origin from 49 to 63 countries, we use the legal origin variables as instruments for banking sector development to assess the effect of banking development on economic growth, capital growth, productivity growth, and private saving rates.

The second econometric technique that we use to control for simultaneity bias also eliminates any omitted variable bias induced by country-specific effects. We use a panel dataset, with data averaged over each of the seven 5-year periods between 1960 and 1995. We use a GeneralizedMethod-of-Moments (GMM) estimator proposed by Arellano and Bover (1995) and Blundell and Bond (1997) to extract consistent and efficient estimates of the impact of banking sector development on growth and the sources of growth. Specifically, dynamic panel procedures typically take first differences of the observations in levels to eliminate country-specific effects [Arellano and Bond 1991; Holtz-Eakin, Newy, and Rosen 1990]. Then, lagged values of the regressors from the levels regression are used as instruments to eliminate inconsistency arising from simultaneity bias. This difference dynamic-panel estimator, however, frequently suffers from weak instruments, which produces biases in finite samples and inefficiencies even asymptotically [Alonso-Borrego and Arellano 1996]. To mitigate this problem, we use a system estimator. Besides the difference dynamic-panel equations, we

\footnotetext{
${ }^{3}$ Also, see the time-series studies by Rousseau and Wachtel (1988) and Neusser and Kugler (1998).
} 
simultaneously estimate the level equations where the instruments are lagged values of the differenced regressors [Arellano and Bover 1995]. By ameliorating the weak instrument deficiency, this system estimator dramatically improves the consistency and efficiency of the estimator [Blundell and Bond 1997]. Thus, this paper uses two econometric procedures - a pure cross-sectional instrumental variable estimator and a GMM dynamic panel technique - to evaluate the impact of differences in banking sector development on economic growth, capital accumulation, productivity growth, and private saving.

The second major way in which this paper improves upon existing work is by using better measures of saving rates, physical capital, productivity, and banking sector development. Private saving rates are notoriously difficult to measure [Masson et al. 1995]. As detailed below, however, we use the results of a recent World Bank initiative that compiled high-quality statistics on gross private savings as a share of gross private disposable income for a broad cross-section of countries over the period 19711995[Loayza, Lopez, Schmidt-Hebbel and Serven 1998]. We also use more accurate estimates of physical capital stocks. Researchers typically make an initial estimate of the capital stock in 1950 and then use aggregate investment data to compute capital stocks in later years [King and Levine 1994; Nehru and Dhareshwar 1994]. These estimates use aggregate investment data that, for example, combine investment in residential structures with investment in equipment and machines, while employing a single depreciation rate. Recently, however, the Penn-World Tables (PWT) 5.6 constructed capital stock data based on disaggregated investment and depreciation data. While the PWT 5.6 discusses remaining measurement problems, these data suffer from fewer shortcomings than existing capital stock data. We also improve on existing measures of aggregate TFP growth. Researchers typically define TFP growth as a residual: real per capita GDP growth minus real per capita capital growth times capital share in the national income accounts, which is commonly taken to be between 0.3 and 0.4 . Thus, simply by using better capital data, we obtain more accurate measures of 
TFP growth. Moreover, aggregate studies of TFP growth frequently ignore human capital accumulation. In contrast, we use both the Mankiw (1995) and the Bils and Klenow (1996) specifications to control for human capital accumulation. Thus, we obtain three improved measures of TFP to examine the impact of banking sector development on productivity growth. Finally, this paper also uses an improved measure of banking sector development. We measure banking sector credits to the private sector relative to GDP. This measure more carefully distinguishes who is conducting the intermediation, to where the funds are flowing, and we more accurately deflate financial stocks than past studies [e.g., King and Levine 1993a,b]. Finally, we check our results using the King and Levine (1993a,b) and Levine and Zervos (1998) measures of financial intermediation after extending their sample periods and deflating correctly.

We find that banks exert a strong, causal impact on real per capita GDP growth and per capita productivity growth. Using both the pure cross-sectional instrumental variable estimator and system dynamic-panel indicator, we find that higher levels of banking sector development produce faster rates of economic growth and total factor productivity growth. These results are robust to alterations in the conditioning information set and to changes in the measure of banking sector development. Thus, the data are consistent with the Schumpeterian view that the level of banking sector development importantly determines the rate of economic growth by affecting the pace of productivity growth and technological change.

Turning to physical capital growth and savings, the results are more ambiguous. We frequently find a positive and significant impact of banks on the rate of capital per capita growth. Nonetheless, the results are inconsistent across alternative measures of financial development in the pure cross-sectional regressions. The data do not confidently suggest that higher levels of banking sector development promote economic growth by boosting the long-run rate of physical capital accumulation. We find 
similarly conflicting results on savings. Different measures of banking sector development yield different conclusions regarding the link between banking sector development and private savings in the both pure cross-section and the panel regressions. Thus, we do not find a robust relationship between banking sector development and either physical capital accumulation or private saving rates. In sum, the results are consistent with the Schumpeterian view of finance and development: banks affect economic development primarily by influencing total factor productivity growth.

The rest of the paper is organized as follows. Section II describes the data and presents descriptive statistics. Section III discusses the two econometric methods. Section IV presents the results for economic growth, capital growth and productivity growth. Section V presents the results for private saving rates. Section VI concludes.

\section{Measuring financial development, growth and its sources}

This section describes the measures of (1) banking sector development, (2) real per capita GDP growth, (3) capital per capita growth, (4) productivity per capita growth, and (5) private saving rates.

\section{A. Indicators of financial development}

A large theoretical literature shows that banks can reduce the costs of acquiring information about firms and managers and lower the costs of conducting transactions. ${ }^{4}$ By providing more accurate information about production technologies and by exerting corporate control, better banks can enhance resource allocation and accelerate growth [Boyd and Prescott 1986; Greenwood and Jovanovic 1990; King and Levine 1993b]. Similarly, by facilitating risk management, improving the liquidity of assets available to savers, and reducing trading costs, banks can encourage investment in higher-return activities [Obstfeld 1994; Bencivenga and Smith 1991; Greenwood and Smith 1997]. The effect of 
better banks on savings, however, is theoretically ambiguous. Higher returns ambiguously affect saving rates due to well-known income and substitution effects. Also, greater risk diversification opportunities have an ambiguous impact on saving rates as shown by Levhari and Srinivasan (1969). Moreover, in a closed economy, a drop in saving rates in the presence of a production function with physical capital externalities induces a negative impact on growth. Indeed, if these saving and externality effects are sufficiently large, an improvement in banking development could lower growth [Bencivenga and Smith 1991]. Thus, we attempt to shed some empirical light on these debates and ambiguities that emerge from the theoretical literature. Specifically, we examine whether economies with better-developed banks (i) grow faster, (ii) enjoy faster rates of productivity growth, (iii) experience more rapid capital accumulation, and (iv) have higher saving rates.

To evaluate the impact of banks on growth and the sources of growth, we seek an indicator of the ability of banks to research and identify profitable ventures, monitor and control managers, ease risk management, and facilitate resource mobilization. We do not have a direct measure of these financial services. We do, however, construct a better measure of banking sector development than past studies and we check these results with existing measures of financial sector development.

The primary measure of banking sector development is PRIVATE CREDIT, which equals the value of credits by financial intermediaries to the private sector divided by GDP. Unlike many past measures [King and Levine 1993a,b], this measure excludes credits issued by the central banks. Furthermore, it excludes credit to the public sector and cross claims of one group of intermediaries on another. PRIVATE CREDIT is also a broader measure of banking sector development than that used by Levine and Zervos (1998) since it includes all financial institutions, not only deposit money banks. ${ }^{5}$

\footnotetext{
${ }^{4}$ For overviews of the literature see Gertler (1988) and Levine (1997).

${ }^{5}$ For example, King and Levine (1993a,b) use a measure of gross claims on the private sector divided by GDP. But, this measure includes credits issued by the monetary authority and government agencies, whereas PRIVATE CREDIT
} 
Finally, unlike past studies, we carefully deflate the banking statistics. Specifically, financial stock items are measured at the end of the period, while GDP is measured over the period. Simply dividing financial stock items by GDP, therefore, can produce misleading measures of financial development, especially in highly inflationary environments. ${ }^{6}$ Thus, PRIVATE CREDIT improves significantly on other measures of financial development.

To assess the robustness of our results, we use two other measures of financial development. LIQUID LIABILITIES equals the liquid liabilities of the financial system (currency plus demand and interest-bearing liabilities of banks and nonbank financial intermediaries) divided by GDP. ${ }^{7}$ Unlike PRIVATE CREDIT, LIQUID LIABILITIES is just an indicator of size. The other measure is COMMERCIAL-CENTRAL BANK, the ratio of commercial bank domestic assets divided by commercial bank plus central bank domestic assets. COMMERCIAL-CENTRAL BANK measures the degree to which the banks versus the central banks allocate society's savings. The intuition underlying this measure is that commercial banks are more likely to identify profitable investments, monitor managers, facilitate risk management, and mobilize savings than central banks.

\footnotetext{
includes only credits issued by banks and other financial intermediaries. Also, Levine and Zervos (1998) and Levine (1998a) use a measure of deposit money bank credits to the private sector divided by GDP over the period 1976-1993. That measure, however, does not include credits to the private sector by non-deposit money banks.

6 Some authors try to correct for this problem by using an average of financial intermediary balance sheet items in year $\mathrm{t}$ and t-1 and dividing by GDP measured in year t [King and Levine 1993a]. This however does not fully resolve the distortion. This paper deflates end-of-year financial balance sheet items by end of year consumer price indices (CPI) and deflates the GDP series by the annual CPI. Then, we compute the average of the real financial balance sheet item in year $t$ and $\mathrm{t}-1$ and divide this average by real GDP measured in year $\mathrm{t}$.

${ }^{7}$ Among others it has been used by King and Levine (1993a).
} 


\section{B. Economic growth and its sources}

This paper uses new and better data on capital accumulation, productivity growth and private saving rates. This subsection describes our data on economic growth, capital per capita growth and three different measures of productivity growth. ${ }^{8}$

GROWTH equals the rate of real per capita GDP growth, where the underlying data are from the national accounts. For the pure cross-sectional data (where there is one observation per country for the period 1960-1995), we compute GROWTH for each country by running a least squares regression of the logarithm of real per capita GDP on a constant and a time trend. We use the estimated coefficient on the time trend as the growth rate. This procedure is more robust to differences in the serial correlation properties of the data than simply using the geometric rate of growth [Watson 1992]. ${ }^{9}$ We do not use least squares growth rates for the panel data because the data are only over five-year periods. Instead, we calculate real per capita GDP growth as the geometric rate of growth for each of the seven five-year periods in the panel data.

The capital accumulation data are from a study by Levine and Orlov (1998) and improve significantly on figures from previous studies by using disaggregated data. Briefly, they construct capital stock figures, $K$, from investment data, $I$, and depreciation estimates, $\delta$, for five separate capital categories: machinery, transportation equipment, business construction, residential construction and other construction. These data are from revised Penn-World Tables (5.6). The capital stock number for each category, $i$, is then computed using the following formula: $\mathrm{K}_{\mathrm{i}, t+1}=\mathrm{K}_{\mathrm{i}, \mathrm{t}}+\mathrm{I}_{\mathrm{i}, \mathrm{t}}-\delta_{\mathrm{i}, \mathrm{K}, \mathrm{t}, \mathrm{t}}$. This perpetual inventory method requires the estimate of an initial capital stock $\mathrm{K}_{0}$. Levine and Orlov (1998) use Harberger's (1978) suggestion for deriving a guess of the initial capital stock in 1950, which

\footnotetext{
${ }^{8}$ For a detailed description of sources and construction of the data see appendix B.

${ }^{9}$ Using geometric growth rates yields virtually identical results.
} 
assumes that each country was at its steady-state capital-output ratio in 1950. While this assumption is surely wrong, it is probably better than assuming that an initial capital stock of zero, which many researchers use. ${ }^{10}$ Despite remaining difficulties, these capital figures improve significantly on previous studies. CAPGROWTH is the growth rate of the physical per capita capital stock.

We use three different methods to construct measures of productivity per capita growth. All of them are residuals from aggregate production functions. The first measure (PROD1) builds on the neoclassical production function with physical capital $K$, labor $L$ and the level of total factor productivity $A$. We assume that this aggregate production function is common across countries and time.

$$
Y_{i}=A_{i} K_{i}^{\alpha} L_{i}^{1-\alpha}
$$

Assuming a capital share $\alpha=0.3$, the productivity per capita growth rate is given by

$$
P R O D 1=G R O W T H-0.3 * C A P G R O W T H
$$

This first measure of total factor productivity growth ignores human capital accumulation. Our other two productivity measures therefore include a measure of human capital, $H$, in the aggregate production function. We use the average years of schooling in the total population over 15 [Barro and Lee 1996] as proxy for the human capital stock in the economy.

PROD2 follows Mankiw (1995) and adds human capital to an augmented neoclassical production function of the following form:

$$
Y_{i}=A_{i} K_{i}^{\alpha} H_{i}^{\gamma} L^{1-\alpha-\gamma}
$$

\footnotetext{
${ }^{10}$ Note, alternative measures of capital growth based on assuming an initial capital stock of zero, tend to produce similar cross-country characterizations of capital growth as discussed in King and Levine (1994).
} 
We assume $\alpha=0.3$, as above and $\gamma=0.5$, as Mankiw. ${ }^{11}$ Thus, our second measure of productivity per capita growth, $P R O D 2$, is then given by:

$$
P R O D 2=G R O W T H-0.3 * C A P G R O W T H-0.5 * G S C H O O L
$$

where GSCHOOL is the growth rate in average years of schooling.

Our third measure of total factor productivity growth follows Hall and Jones (1998) and Bils and Klenow (1996) in specifying the role of human capital in the aggregate production function. Specifically, let the aggregate production function be given by

$$
Y_{i}=K_{i}^{\alpha}\left(A_{i} H_{i}\right)^{1-\alpha}
$$

where $H$ is human capital augmented labor and $A$ is labor-augmenting productivity. Assuming that labor $L$ is homogeneous within a country and that each unit has received $E$ years of schooling, we can write human capital augmented labor as follows:

$$
H_{i}=e^{\phi\left(E_{i}\right)} L_{i}
$$

The function $\phi(E)$ reflects the efficiency of a unit of labor with $E$ years of schooling relative to one with no schooling $(\phi(0)=0)$ and the derivative $\phi^{\prime}(E)$ is the return to schooling estimated in a Mincerian wage regression [Mincer 1974]. Following Hall and Jones (1998) and estimations by Psacharopoulos (1994) we assume that $\phi(E)$ is piecewise linear, and the following rates of return: $13.4 \%$ for the first 4 years, $10.1 \%$ for the following 4 years and $6.8 \%$ beyond the $8^{\text {th }}$ year. ${ }^{12}$ Solving our model for the growth rate of $A$, we define PROD 3 as: ${ }^{13}$

\footnotetext{
${ }^{11}$ Mankiw presents two arguments for the assumption of $\gamma=0.5$. First, in the U.S. the minimum wage is about one third of the average wage rate, which suggests that about two thirds of the labor income is return to human capital. Second, the return to schooling is at least 9.8\% and the average American has 12 years of education (Psacharopoulos 1994 and Barro and Lee 1996), which implies that the average worker earns almost three times as much as he would without any schooling. Again, this suggests that two thirds of labor income are return to human capital.

${ }^{12}$ These rates of return are based on averages for sub-Saharan Africa, the whole world and the OECD, respectively.

${ }^{13} \mathrm{We}$ get this result a follows. We first divide (5) by $\mathrm{L}_{\mathrm{i}}$ and take logs. Note that due to the assumed functional form $\varnothing(\mathrm{E})=$ $\mathrm{E}_{\mathrm{i}}^{*} \emptyset^{\prime}\left(\mathrm{E}_{\mathrm{i}}\right)$, so that $\ln \left(\mathrm{H}_{\mathrm{i}} / \mathrm{L}_{\mathrm{i}}\right)=\mathrm{E}_{\mathrm{i}}^{*} \emptyset^{\prime}\left(\mathrm{E}_{\mathrm{i}}\right)$. Solving the equation for the log of productivity per capita and taking first differences results in (7).
} 


$$
\text { PROD3 }=\left[\text { GROWTH }-0.3^{*} \text { CAPGROWTH }-0.7^{*} \Delta\left(E^{*} \phi^{\prime}(E)\right)\right] / 0.7
$$

\section{Private Saving Rates}

The data on private saving rates draw on a new savings database recently constructed at the World Bank, and described in detail in Loayza, Lopez, Schmidt-Hebbel and Serven (1998). This database improves significantly on previous data sets on savings in terms of accuracy, and both countryand year-coverage. These data draw on national accounts data, and are checked for consistency using individual country sources.

The private saving rate is calculated as the ratio of gross private saving to gross private disposable income. Gross private saving is measured as the difference between gross national saving (gross national disposable income minus consumption expenditures, both measured at current prices) and gross public saving (the public sector is defined as the consolidated central government). ${ }^{14}$ Gross private disposable income is measured as the difference between gross national disposable income and gross public disposable income (sum of public saving and consumption).

Due to data availability, the private saving rate sample is slightly different from the sample used in the analysis of real per capita GDP growth, capital per capita growth and productivity per capita growth. Specifically, we have data available from 1971 - 1995, so that we have five non-overlapping five-year periods for the panel data set and 25 years for the cross-country estimations.

\section{Descriptive Statistics and Correlations}

Table 1 presents descriptive statistics and correlations between PRIVATE CREDIT and the different dependent variables. There is a considerable variation in financial development across

\footnotetext{
${ }^{14}$ Using a broader measure of the public sector, instead of the consolidated central government, would be analytically
} 
countries, ranging from a low of $4 \%$ in Zaire to a high of $141 \%$ Switzerland. GDP per capita growth and capital per capita growth also show significant variation. Korea has the highest growth rates, both for real per capita GDP and for capital per capita, with $7.16 \%$ and $10.51 \%$, respectively. Zaire has the lowest GDP per capita growth rate with $-2.81 \%$, whereas Zimbabwe has the lowest capital per capita growth rate with $-1.84 \%$. Private saving rates also show considerable cross-country variation. Sierra Leone has a private saving rate of $1.05 \%$, whereas Japan's rate is $33.92 \%$. Notably, PRIVATE CREDIT is significantly correlated with all of our dependent variables. Also, the three productivity growth measures have cross correlations of at least $94 \%$.

\section{Methodology}

This section describes the two econometric methods that we use to control for the endogenous determination of banking sector development with growth and the sources of growth. We first use a traditional cross-sectional, instrumental variable estimator. As instruments, we use the legal origin of each country to extract the exogenous component of banking sector development in the pure crosssectional regressions. We also use a cross-country, time-series panel of data and employ dynamic panel techniques to estimate the relationship between financial development and growth, capital accumulation, productivity growth, and saving rates. We describe each procedure below.

preferable. This, however, limits the sample size. Nonetheless, this definition of the public sector yields very similar results to those presented below. 


\section{A. Cross-country regressions with instrumental variables}

\section{Legal origin and financial development}

To control for potential simultaneity bias, we first use instrumental variables developed by LLSV (1998). Legal systems with European origins can be classified into four major legal families [Reynolds and Flores 1996]: the English common law, and the French, German, and Scandinavian civil law countries. ${ }^{15}$ All four families descend from the Roman law as compiled by Byzantine Emperor Justinian in the sixth century and developed by the Glossators, Commentators, and in Canon Law through the $13^{\text {th }}$ century. The four legal families developed distinct characteristics during the last 5 centuries. In the $17^{\text {th }}$ and $18^{\text {th }}$ centuries the Scandinavian countries formed their own legal codes. The Scandinavian legal systems have remained relatively unaffected from the far reaching influences of the German and especially the French Civil Codes.

The French Civil Code was written in 1804, under the directions of Napoleon. Through occupation, it was adopted in other European countries, such as Italy and Poland. Through its influence on the Spanish and Portuguese legal systems, the legal French tradition spread to Latin America. Finally, through colonization, the Napoleonic code was adopted in many African countries, Indochina, French Guyana and the Caribbean.

The German Civil Code (Bürgerliches Gesetzbuch) was completed almost a century later in 1896. The German Code exerted a big influence on Austria and Switzerland, as well as China (and hence Taiwan), Czechoslovakia, Greece, Hungary, Italy, and Yugoslavia. Also, the German Civil Code heavily influenced the Japanese Civil Code, which helped spread the German legal tradition to Korea.

\footnotetext{
${ }^{15}$ This does not include countries with "communist" or Islamic legal systems.
} 
Unlike these civil law countries, the English legal system is common law, where the laws were primarily formed by judges trying to resolve particular cases. Through colonialism it was spread to many African and Asian countries, Australia, New Zealand and North America.

There are two conditions under which the legal origin variables serve as appropriate instruments for financial development. First, they have to be exogenous to economic growth during our sample period. Second, they have to be correlated with financial intermediary development. In terms of exogeneity, the English, French and German legal systems were spread mainly through occupation and colonialism. Thus, we take the legal origin of a country as an exogenous "endowment." In terms of the links between legal origin and financial intermediary development, a growing body of evidence suggests that legal origin helps to shape financial development. LLSV (1998) show that the legal origin of a country materially influences its legal treatment of shareholders, the laws governing creditor rights, the efficiency of contract enforcement, and accounting standards. Shareholders' rights enjoy greater protection in common law countries than in civil law countries, whereas creditors' rights are best protected in German origin countries. French Civil Law countries are comparatively weak both in terms of shareholder and credit rights. In terms of accounting standards, French origin countries tend to have company financial statements that are comparatively less comprehensive than countries with different legal origins. These legal, regulatory and informational characteristics affect the operation of financial intermediaries as shown in LLSV (1997), Levine (1998, 1999), and Levine, Loayza, and Beck (1998).

\section{Cross-country estimation}

In the pure cross-sectional analysis we use data averaged for 63 countries over 1960-95, such that there is one observation per country. ${ }^{16}$ The basic regression takes the form:

\footnotetext{
${ }^{16}$ The cross-country sample for private saving has 61 countries over the period 1971-95.
} 


$$
Y_{i}=\alpha+\beta \text { FINANCE }_{i}+\gamma^{\prime} X_{i}+\varepsilon_{i}
$$

where $\mathrm{Y}$ is either GROWTH, CAPGROWTH, PROD1, PROD2, PROD3 or SAVING. FINANCE equals PRIVATE CREDIT, and LIQUID LIABILITIES or COMMERCIAL-CENTRAL BANK in the robustness tests. $X$ represents a vector of conditioning information that controls for other factors associated with economic growth and $\varepsilon$ is the white noise error term. ${ }^{17}$

To examine whether cross-country variations in the exogenous component of financial intermediary development explain cross-country variations in the rate of economic growth, the legal origin indicators are used as instrumental variables for FINANCE. Specifically, given the vector $Z$ of instrumental variables and assuming that $\mathrm{E}[\varepsilon]=0$, this results in a set of orthogonality conditions $E\left[Z^{\prime} \varepsilon\right]=0$. We can use standard GMM techniques to estimate our model, which produces instrumental variable estimators of the coefficient in (8). After computing these GMM estimates, the standard Lagrange-Multiplier test of the overidentifying restrictions assesses whether the instrumental variables are associated with growth beyond their ability to explain cross-country variation in financial sector development. Under the null-hypothesis that the instruments are not correlated with the error terms, the test is distributed $\chi^{2}$ with $(J-K)$ degrees of freedom, where $J$ is the number of instruments and $K$ the number of regressors. The estimates are robust to heteroskedasticity.

\section{B. Dynamic panel techniques}

The cross-country estimations help us determine whether the cross-country variance in economic growth and the other dependent variables can be explained by variance in financial

\footnotetext{
${ }^{17}$ Due to the potential nonlinear relationship between economic growth and the assortment of economic indicators, we use natural logarithms of the regressors in the regressions of GROWTH, CAPGROWTH, PROD1, PROD2 and PROD3.
} 
development. But we also would like to know whether changes in financial development over time within a country have an effect on economic growth through its various channels. We also gain degrees of freedom by adding the variability of the time-series dimension: the "within" standard deviation of PRIVATE CREDIT in our panel data set is $15.1 \%$, compared to a "between" standard deviation of $28.4 \%$, whereas for real per capita GDP growth the values are $2.4 \%$ versus $1.7 \%{ }^{18}$ So there is a considerable additional variability to exploit.

The panel consists of data for 77 countries averaged over the period 1960-95. We average the data over seven non-overlapping five-year periods. ${ }^{19}$ In the following, the subscript $t$ therefore refers to one of these five-year periods.

\section{Dynamic panel: Econometric problems}

We want to explore regressions of the following form:

$$
y_{i, t}=\alpha^{\prime} X_{i, t-1}^{1}+\beta^{\prime} X_{i, t}^{2}+\mu_{i}+\lambda_{t}+\varepsilon_{i, t}
$$

where y represents our dependent variable, $X^{1}$ represents a set of lagged explanatory variables and $X^{2}$ a set of contemporaneous explanatory variables, $\mu$ is an unobserved country-specific effect, $\lambda$ is a timespecific effect, $\varepsilon$ is the white-noise error term, and $i$ and $t$ represent country and time period, respectively. There are two econometric problems when estimating equation (9).

1. The unobserved country-specific effect is part of the error term. Therefore, a possible correlation between $\mu$ and other explanatory variables results in biased coefficient estimates. Furthermore, if the lagged dependent variable is included in $X^{I}$, the country-specific effect is correlated with it.

\footnotetext{
${ }^{18}$ The "within" standard deviation is calculated using the deviations from country averages, whereas the "between" standard deviation is calculated from the country averages. The fact that the "between" standard deviations in the panel are not the same as in the cross-section sample results from the different country coverage.

${ }^{19}$ The panel sample for private saving includes 72 countries and five 5-year periods between 1971 and 1995.
} 
Under assumptions for the country-specific effect that we explain below, we control for the presence of correlated specific effects.

2. A subset of the explanatory variables may not be exogenous. Thus, endogeneity bias may lead to inappropriate inferences. Specifically, we assume that all the explanatory variables are weakly exogenous. This means that the explanatory variables are uncorrelated with future realizations of the error term and thus are not affected by future realizations of the dependent variable. The explanatory variables, however, may be affected by current and past realizations of the dependent variable. This assumption allows for the possibility of simultaneity and reverse causality.

2. Dynamic panels: A GMM estimator ${ }^{20}$

Arellano and Bond (1991) propose to first-difference the regression equation to eliminate the country-specific effect.

$$
y_{i, t}-y_{i, t-1}=\alpha^{\prime}\left(X_{i, t-1}^{1}-X_{i, t-2}^{1}\right)+\beta^{\prime}\left(X_{i, t}^{2}-X_{i, t-1}^{2}\right)+\left(\varepsilon_{i, t}-\varepsilon_{i, t-1}\right)
$$

This procedure solves the first econometric problem, as described above, but introduces a correlation between the new error term $\varepsilon_{\mathrm{i}, \mathrm{t}}-\varepsilon_{\mathrm{i}, \mathrm{t-1}}$ and the lagged dependent variable $y_{i, t-1}-y_{i, t-2}$ if it is included in $X_{i, t-1}^{l}-X_{i, t-2 .}^{l}$ To address this and the endogeneity problem, Arellano and Bond propose using the lagged values of the levels of the variables as instruments. Under the assumptions that there is no serial correlation in the error term $\varepsilon$ and that the explanatory variables $\mathrm{X}$ are weakly exogenous, we can use the following moment conditions:

$$
E\left[X_{i, t-s} \cdot\left(\varepsilon_{i, t}-\varepsilon_{i, t-1}\right)\right]=0 \quad \text { for } s \geq 2 ; t=3, \ldots, T
$$

\footnotetext{
${ }^{20}$ Chamberlain (1984), Holtz-Eakin, Newey and Rosen, Arellano and Bond (1991) and Arellano and Bover (1995) proposed the General Method of Moments (GMM) estimator. The GMM estimator has been applied to cross-country studies, by, among others, Caselli, Esquivel and Lefort (1996), Easterly, Loayza and Montiel (1997) and Fajnzylber, Lederman and Loayza (1998).
} 
Using these moment conditions, Arellano and Bond propose a two-step GMM estimator. In the first step the error terms are assumed to be independent and homoskedastic across countries and over time. In the second step, the residuals obtained in the first step are used to construct a consistent estimate of the variance-covariance matrix, thus relaxing the assumptions of independence and homoskedasticity. We will refer to this estimator as difference estimator.

There are several conceptual and econometric shortcomings with the difference estimator. First, by first-differencing we loose the cross-country dimension and exploit only the time-series dimension within countries. Second, differences of the explanatory variables are often less correlated over time than the levels. This may produce biases estimates if the dynamic structure of the estimated model (the differenced equation) differs from the true model as noted by Barro (1997). Third, differencing may decrease the signal-to-noise ratio thereby exacerbate measurement error biases (see Griliches and Hausman, 1986). Finally, Alonso-Borrego and Arellano (1996) and Blundell and Bond (1997) show that if the lagged dependent and the explanatory variables are persistent over time, lagged levels of these variables are weak instruments for the regressions in differences. Simulation studies show that the difference estimator has a large finite-sample bias and poor precision, especially in samples with a small time-series dimension.

To address these conceptual and econometric problems, we use an alternative estimator that combines in a system the regressions in differences with regression in levels, as proposed by Arellano and Bover (1995). Blundell and Bond (1997) show that this system estimator reduces the potential biases and imprecision associated with the difference estimator. The instruments for the regressions in differences are the same as above. For the regressions in level we use lagged differences as instruments. The latter are valid instruments under the following assumption. Although there might be a correlation between $\mu$ and the levels of the other explanatory variables, this correlation is constant over time: 


$$
E\left[X_{i, t+p} \cdot \mu_{i}\right]=E\left[X_{i, t+q} \cdot \mu_{i}\right] \quad \text { for all } p \text { and } q
$$

Under this assumption there is no correlation between the differences of the explanatory variables and the country-specific effect, and lagged differences are therefore valid instruments. The moment conditions for the regressions in levels are thus ${ }^{21}$ :

$$
E\left[\left(X_{i, t-s}-X_{i, t-s-1}\right) \cdot\left(\varepsilon_{i, t}+\mu_{i}\right)\right]=0 \quad \text { for } s=1 ; t=3, \ldots, T
$$

The system thus consists of the stacked regressions in differences and levels, with the moment conditions in (11) applied to the first part of the system, the regressions in differences, and the moment conditions in (13) applied to the second part, the regressions in levels. As with the difference estimator, the model is estimated in a two-step GMM procedure generating consistent and efficient coefficient estimates. $^{22}$

The consistency of the GMM estimator depends on the validity of the assumption that $\varepsilon$ does not exhibit serial correlation and on the validity of the instruments. We use two tests proposed by Arellano and Bond (1991) to test for these assumptions. The first is a Sargan test of over-identifying restrictions, which tests the overall validity of the instruments by analyzing the sample analog of the moment conditions used in the estimation procedure. Under the null-hypothesis of the validity of the instruments this test is distributed $\chi^{2}$ with $(J-K)$ degrees of freedom, where $J$ is the number of instruments and $K$ the number of regressors. The second test examines the assumption of no serial correlation in the error terms. We test whether the differenced error term is second-order serially

\footnotetext{
${ }^{21}$ Given that lagged levels are used as instruments in the difference regressions, only the most recent difference is used as instrument in the level regressions. Using additional differences would result in redundant moment conditions (see Arellano and Bover 1995).

${ }^{22}$ We are grateful to Stephen Bond for providing us with a program to apply his and Arellano's estimator to an unbalanced panel data set.
} 
correlated. ${ }^{23}$ Under the null-hypothesis of no second-order serial correlation, this test is distributed standard-normal. Failure to reject the null hypotheses of both tests gives support to our model.

\section{Finance and the channels to economic growth}

This section presents the results of the cross-country and panel regressions of real per capita GDP growth, productivity per capita growth, and capital per capita growth on financial development and a conditioning information set.

\section{A. The conditioning information sets}

To assess the strength of an independent link between financial development and the growth variables we use various conditioning information sets. The simple conditioning information set includes the logarithm of initial real per capita GDP to control for convergence and the average years of schooling as indicator of the human capital stock in the economy. The policy conditioning information set includes the simple conditioning information set plus four additional policy variables, that have been identified by the empirical growth literature as being correlated with growth performance across countries (Barro 1991; Easterly, Loayza, and Montiel 1997). We use the inflation rate and the ratio of government expenditure to GDP as indicators of macroeconomic stability. We use the sum of exports and imports as share of GDP and the black market premium to capture the degree of openness of an economy. In our sensitivity analysis for the cross-country regressions, we will also

\footnotetext{
${ }^{23}$ By construction the error term is likely to be first-order serially correlated. We cannot use the error terms from the regression in levels since they include the country-specific effect $\mu$.
} 
include the number of revolutions and coups, the number of assassination per thousand inhabitants, and a measure of ethnic diversity. ${ }^{24}$

\section{B. Finance and Economic Growth}

The results in Table 2 show a statistically and economically significant relationship between the exogenous component of financial intermediary development and economic growth. The first two columns report the results of the pure cross-country regressions using the simple and the policy conditioning information set. PRIVATE CREDIT is significantly correlated with long-run growth at the 5\% significance level in both regressions and the LM-test of overidentifying restrictions indicates that the orthogonality conditions cannot be rejected at the $5 \%$ level. Thus, we do not reject the null hypothesis that the instruments are appropriate. The strong link between finance and growth does not appear to be driven by simultaneity bias. The variables in the conditioning information set also have the expected sign, except for inflation. Consistent with Boyd, Levine, and Smith (1999), we find that inflation affects growth by influencing financial sector performance. Specifically, when we omit PRIVATE CREDIT from the regressions in Table 2, inflation enters with a negative, statistically significant, and economically large coefficient. However, when we control for the level of banking sector development, inflation enters positively and insignificantly.

The results are economically significant. For example, Mexico's value for PRIVATE CREDIT over the period 1960-95 was $22.9 \%$ of GDP. An exogenous increase in PRIVATE CREDIT that had brought it up to the sample median of $27.5 \%$ would have resulted in a 0.4 percentage point higher real per capita GDP growth per year. ${ }^{25}$

\footnotetext{
${ }^{24}$ We cannot use the full conditioning information set in the panel estimations since there is not enough time series variation in the additional three variables.

${ }^{25}$ This result follows from $\ln (27.5)-\ln (22.9)=0.18$ and $0.18 * 2.2=0.4$, where 2.2 is the smaller of the two parameter values on PRIVATE CREDIT in the cross-country regressions.
} 
The dynamic panel estimates also indicate that banking sector development has an economically large causal impact on economic growth. Columns 3 and 4 in table 2 report the results of the panel regressions. PRIVATE CREDIT is significant at the 5\% level with both conditioning information sets. The variables in the conditioning information set have significant coefficients with the expected sign. Furthermore, our tests indicate that our econometric specification and the assumption of no serial correlation in the white-noise error terms cannot be rejected.

\section{Finance and Productivity Growth}

The results in Table 3 show that banking sector development has a large, significant impact on productivity growth. Here we use the first of our productivity growth measures, PRODI. The LM-test for overidentifying conditions shows that the data do not reject the orthogonality conditions at the $5 \%$ level. The variables in the conditioning information set have the expected sign except for inflation, and initial income, openness and the schooling variable in the simple conditioning information set are significant at the $5 \%$ level.

The results for the panel regressions confirm the pure cross-country estimates. The strong link between PRIVATE CREDIT and productivity growth is not due to simultaneity bias of omitted variable bias. The p-values for the Sargan test and the serial correlation test indicate the appropriateness of our instruments and the lack of serial correlation in $\varepsilon$.

Table 4 shows that the impact of PRIVATE CREDIT on productivity growth is robust to the use of alternative measures of productivity growth. Due to the lack of sufficient schooling data, we loose five countries when controlling for human capital accumulation. PRIVATE CREDIT is significant across all three productivity growth measures. This holds using both the simple and the 
policy conditioning information set and using both cross-country and panel estimation techniques. The test statistics do not reject our econometric specification for the cross-country and the panel regressions.

\section{Finance and Capital Growth}

The empirical relationship between banking sector development and physical capital accumulation is less robust than the link between banking sector development and productivity growth. The Table 5 results indicate that PRIVATE CREDIT enters significantly at the $5 \%$ level in both the pure cross-country and the dynamic panel regressions. In the case of the cross-section estimator, we reject the LM-test of overidentifying restrictions when using the simple conditioning information set. However, when we expand the conditioning information set, the cross-sectional estimator passes the specification test. Thus, PRIVATE CREDIT exhibits a strong, positive link with capital growth that does not appear to be driven by simultaneity bias. Nevertheless, other measures of banking sector development do not produce the same results. In the pure cross-section results, none of the other measures of financial sector development enjoy a significant link with capital growth as we discuss below in the subsection on sensitivity results. ${ }^{26}$ The panel results are more robust. Banking sector development is positively and significantly correlated with capital accumulation when using alternative conditioning information sets and alternative measures of banking sector development. The test statistic for serial correlation, however, rejects the null hypothesis of no serial correlation at the $5 \%$ level when using the simple conditioning information set and at the $10 \%$ level when using the policy information set. By including the private saving rate or lagged values of capital growth in the conditioning information set, however, we (i) eliminate the serial correlation, (ii) find a positive impact of banking

\footnotetext{
${ }^{26}$ For completeness, we can get the other measures of financial sector development to enter with positive and significant coefficients in the capital growth equations by using alternative conditioning information sets. But, the other measures
} 
sector development on physical capital growth, and (iii) obtain very similar coefficient estimates to those reported in Table $5 .{ }^{27}$ The difference between the panel and cross-country results may reflect data frequency. While the long-run relationship between capital accumulation and banking development is not robust to alternations in different measures of banking development, the short-term relationship which may reflect business cycle activity - is positive and robust.

\section{E. Sensitivity Analyses}

Table 6 presents the coefficients on all three measures of financial development in cross-country and panel regressions with real per capita GDP growth as dependent variable, using both conditioning information sets. The coefficient estimates for both LIQUID LIABILITIES and COMMERCIALCENTRAL BANK are significantly positive across both samples and both conditioning information sets. All regressions pass the different specification tests. We also ran the regressions with the full conditioning information set in the cross-country sample with similar results. These results strengthen the hypothesis of a statistically and economically significant causal impact of the exogenous component of financial development on economic growth.

Table 7 presents the coefficient estimates for the regressions with the three different measures of productivity growth. The significant, positive coefficient estimates for our two alternative indicators of financial development confirm our previous results. The results with the full conditioning information set yields similar results as the policy conditioning information set.

Table 8 presents the corresponding results for capital per capita growth. Unlike PRIVATE CREDIT, LIQUID LIABILITIES and COMMERCIAL-CENTRAL BANK do not seem to have a

\footnotetext{
are not significant when using the simple or policy conditioning information sets.

${ }^{27}$ The results are available on request. We do not include the results here because we wanted to keep a uniform set of control variables across the growth and sources of growth equations. Since the resulting coefficient estimates are of similar magnitude and significance, we merely want to make the point that the serial correlation reflected in Table 5 is not
} 
significant impact on capital per capita growth in the cross-country sample. In the panel estimations, both financial intermediary development indicators exert a causal impact on capital per capita growth. But, only in the regressions with COMMERCIAL-CENTRAL BANK is the null hypothesis of no serial correlation in the error term not rejected. Thus, while evidence suggests that banking sector development positively influences physical capital accumulation, the pure, cross-sectional relationship between physical capital growth and banking sector development is highly dependent on the measure of banking sector development used.

\section{Finance and Private Saving}

This section explores the impact of the exogenous component of financial development on private saving rates. As in the previous section, we will use both cross-country and panel samples, but a different set of conditioning information.

\section{A. The conditioning information set}

The set of conditioning information is determined by the different theories of consumption. The permanent income hypothesis focuses on an infinitely lived representative agent, whereas the life-cycle hypothesis derives its predictions from an overlapping generation model. We can distinguish between two groups of determinants: income-related and demographic determinants.

Both income level and income growth (measured by the gross private disposable income) have ambiguous signs in saving functions, depending on whether it is permanent or temporary income and whether the increase takes place within a generation or across generations. The same argumentation holds for the terms of trade, which can be considered an exogenous determinant of income. A higher 
real interest rate has a negative substitution and a positive income effect on consumption, which again results in an ambiguous sign. We include the inflation rate as a proxy for uncertainty, expecting a positive correlation between saving and the inflation rate.

We include several demographic variables, as the old-age and young-age population dependency ratios (defined as ratio of the population under 15 to the total population and ratio of population over 65 to the total population, respectively) and the share of urban population in total population. Including the dependency ratios helps to discriminate between the life-cycle and the permanent income hypothesis. The life-cycle hypothesis predicts a negative sign, whereas the permanent income hypothesis predicts insignificance. Since agents engaged in agricultural activities face a higher income uncertainty, economies with a higher urban population share should have lower private savings rates. The opposite effect, however, might result, if urban consumers have easier and better access to financial intermediaries.

Finally we include the share of government savings in GPDI, to test for the validity of the Ricardian equivalence theorem. A coefficient estimate of minus 1 would provide evidence in favor of the Ricardian hypothesis.

\section{B. Regressions Results}

The results in tables 9 and 10 do not suggest that banking sector development exerts a strong, positive effect on private saving rates. Whereas the coefficient on PRIVATE CREDIT is significantly positive in the cross-country regression, it is insignificant in the panel regression. The results for the cross-country regression indicate a small positive effect of financial development on private saving rates. The LM-Test of overidentifying restrictions indicates that the orthogonality conditions cannot be rejected at the 5\% level and that the instruments are therefore appropriate. 
The panel estimations, however, indicate an insignificant impact of PRIVATE CREDIT on private savings rates. The econometric specification tests indicate that we cannot reject the null hypotheses of the appropriateness of the instruments and the assumption of no serial correlation of the differenced error terms. The results seem to indicate that there is a small long-run, but not a short-run impact of financial intermediary development on private saving rates. As shown in Table 10, alternative measures of banking sector development do not clarify the ambiguous relationship between financial development and private savings. 


\section{Conclusions}

This paper examined the causal impact of financial development on growth and its sources. We use two econometric methods. To assess the long-run impact of the exogenous component of financial development on economic growth and its sources we use a cross-country sample with data averaged over the period 1960-95 and the legal origin of countries as instruments. To exploit the time-series nature of the data, we create a panel data set and use recent dynamic panel techniques as proposed by Arellano and Bond (1991), Arellano and Bover (1995) and Blundell and Bond (1997). This procedure controls for the country-specific effect and the possible endogeneity of the regressors.

We find a significantly positive causal impact of financial development on real per capita growth and productivity per capita growth. This result is robust to the use of different estimation procedures, conditioning information sets, and indicators of financial development. The picture is more ambiguous in regressions with physical capital per capita growth and saving. While there tends be a positive link between banking sector development and both physical capital accumulation and private saving rates, these results are sensitive to alterations in estimation techniques and measures of banking sector development. This paper's results support the view that better functioning banks improve resource allocation and accelerate total factor productivity growth with positive repercussions for long-run economic growth. 


\section{REFERENCES}

Alonso-Borrego, C. and Arellano, Manuel. "Symmetrically Normalised Instrumental Variable Estimation Using Panel Data,” CEMFI Working Paper No. 9612, September 1996.

Arellano, Manuel and Bond, Stephen. "Some Tests of Specification for Panel Data: Monte Carlo Evidence and an Application to Employment Equations," Review of Economic Studies 1991, 58, pp. 277-297.

Arellano, Manuel, and Bover, Olympia. "Another look at the Instrumental-Variable Estimation of ErrorComponents Models," Journal of Econometrics 1995, 68, pp. 29-52.

Barro, Robert J. "Economic Growth in a Cross Section of Countries", Quarterly Journal of Economics 1991, 56 (2), pp. 407-443.

Barro, Robert J. Determinants of Economic Growth: A Cross-country Empirical Study. Cambridge, MA: The MIT Press, 1997.

Barro, Robert J and Lee, Jong-Wha. "International Measures of Schooling Years and Schooling Quality", AER Papers and Proceedings 1996, 6ㅜ, pp. 218-223.

Bencivenga, Valerie R., and Smith, Bruce D. "Financial Intermediation and Endogenous Growth,"

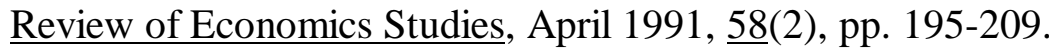

Bils, Mark and Klenow, Peter J. “Does Schooling Cause Growth or the Other Way Around?”, NBER Working Paper 6393, February 1998.

Blundell, Richard and Bond, Stephen. "Initial Conditions and Moment Restrictions in Dynamic Panel Data Models,” University College London Discussion Paper 97-07, 1997.

Bond, Stephen; Hoeffler, Anke; and Temple, Jonathan. "Panel Data Estimators and Cross-Country Growth Regressions: A Cautionary Tale," Hertford College, Oxford mimeo, 1997.

Boyd, John H.; Levine, Ross; and Smith, Bruce D. "The Impact of Inflation on Financial Sector Performance." January 1999. University of Virginia mimeo.

Boyd, John H. and Prescott, Edward C. "Financial Intermediary Coalitions," Journal of Economic Theory, April 1986, 38(2), pp. 211-232.

Caselli, Francesco; Esquivel, Gerardo; and LeFort, Fernando. "Reopening the Convergence Debate: A New Look at Cross-Country Growth Empirics," Journal of Economic Growth, September 1996, 1, pp. 363-389.

Chamberlain, G. "Panel Data", in: Handbook of Econometrics Vol.2 , Eds.: Z. Griliches and M.D. 
Intriligator, Elsevier, Amsterdam, 1984, pp. 1247-1313.

Demirgüç-Kunt, Asli and Maksimovic, Vojislav. "Law, Finance, and Firm Growth," Journal of Finance, December 1998, 53(6), pp.2107-2137.

Diamond, Douglas W. "Financial Intermediation and Delegated Monitoring," Review of Economic Studies, July 1984, 51(3), pp. 393-414.

Easterly, William. "Life During Growth”, mimeo, World Bank, 1998.

Easterly, William; Levine, Ross; and Pritchett, Lant. "Growth: Some Things to Remember", mimeo, The World Bank, 1999.

Easterly, William; Loayza, Norman; and Montiel, Peter. "Has Latin America's Post Reform Growth Been Disappointing?" Journal of International Economics, November 1997, 43(3/4), pp. $287-$ 312.

Faijnzylber, Pablo; Lederman, Daniel; and Loayza, Norman "What Causes Violent Crime," mimeo, March 1998, The World Bank.

Gertler, Mark. "Financial Structure and Aggregate Economic Activity: An Overview," Journal of Money, Credit, and Banking, August 1988, 20(3, Pt. 2), pp. 559-88.

Greenwood, Jeremy and Jovanovic, Boyan. "Financial Development, Growth, and the Distribution of Income," Journal of Political Economy, October 1990, 98 (5, Pt.1), pp. 1076-1107.

Greenwood, Jeremy and Smith, Bruce. "Financial Markets in Development, and the Development of Financial Markets," Journal of Economic Dynamics and Control, January 1997, 21(1), pp. 145186.

Grichiles, Z. and Hausman, J. “Errors in Variables in Panel Data”, Journal of Econometrics 32(3), pp. 93-118.

Hall, Robert E. and Jones, Charles I. "Why Do Some Countries Produce So Much More Output per Worker than Others?”, NBER Working Paper 6564, May 1998.

Harberger, Arnold C. "Perspectives on Capital and Technology in Less Developed Countries," in Contemporary Economic Analysis, Eds: M.J. Artis and A.R. Nobay. 1978. London: Croom Helm.

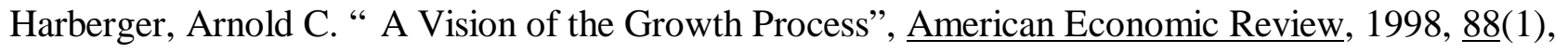
pp.1-32.

Holtz-Eakin, D.; Newey, W, and Rosen, H. "Estimating Vector Autoregressions with Panel Data, “" Econometrica, 1990, 56(6), pp. 1371-1395. 
King, Robert G. and Levine, Ross. "Finance and Growth: Schumpeter Might Be Right," Quarterly Journal of Economics, August 1993a, 108(3), pp. 717-38.

King, Robert G. and Levine, Ross. "Finance, Entrepreneurship, and Growth: Theory and Evidence," Journal of Monetary Economics, December 1993b, 32(3), pp. 513-42.

King, Robert G. and Levine, Ross. "Capital Fundamentalism, Economic Development, and Economic Growth", Carnegie-Rochester Conference Series on Public Policy, 1994, 40, pp. 259-92.

Klenow, Peter J. “ Ideas versus Rival Human Capital: Industry Evidence on Growth Models”, Journal of Monetary Economics, August 1998, 42(1), pp. 3-23.

Laporta, Rafael; Lopez-de-Silanes, Florencio; Shleifer, Andrei; and Vishny, Robert W. "Law and Finance," Journal of Political Economy, December 1998, 106(6), pp. 1113-1155.

Laporta, Rafael; Lopez-de-Silanes, Florencio; Shleifer, Andrei; and Vishny, Robert W. "Legal Determinants of External Finance," Journal of Finance, July 1997, 52(3), pp. 1131-1150.

Levhari, David and Srinivasan, T.N. "Optimal Savings under Uncertainty”, Review of Economic

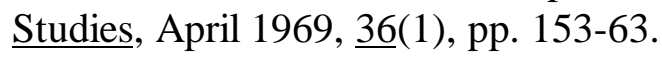

Levine, Ross. "Financial Development and Economic Growth: Views and Agenda," Journal of Economic Literature, June 1997, 35(2), pp. 688-726.

Levine, Ross. "The Legal Environment, Banks, and Long-Run Economic Growth,” Journal of Money, Credit, and Banking, August 1998a, 30(3 pt.2), pp.596-613.

Levine, Ross. “Law, Finance, and Economic Growth”, Journal of Financial Intermedation, forthcoming January 1999.

Levine, Ross; Loayza, Norman; and Beck, Thorsten. "Financial Intermediation and Growth: Causality and Causes", mimeo, World Bank.

Levine, Ross; and Orlov, Alex. "Capital Accumulation Redux”, mimeo, University of Virginia

Levine, Ross and Zervos, Sara. "Stock Markets, Banks, and Economic Growth," American Economic

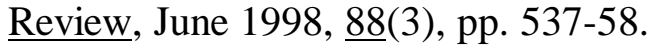

Loayza, Norman; Lopez, Humberto; Schmidt-Hebbel, Klaus; and Serven, Luis “World Saving Database", mimeo 1998, The World Bank.

Mankiw, Gregory N., “The Growth of Nations”, Brookings Papers on Economic Activity, 1995,pp.275-326 
Masson, P., Bayoumi T. and Samiei H. "Saving Behavior in Industrial and Developing Countries", IMF manuscript, 1998.

Mincer, Jacob, “Schooling, Experience, and Earnings, New York: Columbia University Press 1974.

Nehru, Vikram and Dhareshwar, Ashok, "New Estimates of Total Factor Productivity Growth for Developing and Industrialized Countries”, World Bank, Policy Research Working Paper 1313, June 1994.

Neusser, Klaus and Kugler, Maurice. "Manufacturing Growth and Financial Development: Evidence from OECD Countries," Review of Economics and Statistics, November 1998, 80, pp. 636-46.

Obstfeld, Maurice. "Risk-taking, Global Diversification, and Growth”, American Economic Review, December 1994, 84(5), pp.1310-29.

Psacharopoulos, George. "Returns to Investment in Education: A Global Update", World Development, September 1994, 22(9), pp. 1325-43.

Prescott, Edward C. "Needed: A Theory of Total Factor Productivity", International Economic Review, 1998, 39(3), pp.525-51.

Rajan, Raghuram G. and Zingales, Luigi. "Financial Dependence and Growth," American Economic

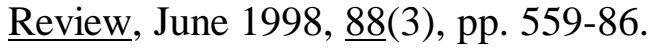

Reynolds, Thomas H. and Flores, Arturo A. Foreign Law Current Sources of Codes and Legislation in Jurisdictions of the World, Fred B. Rothman \& Co. (Littleton Colorado), (AALL Publication Series No. 33). 1996.

Rousseau, Peter L. and Wachtel, Paul. "Financial Intermediation and Economic Performance: Historical Evidence from Five Industrial Countries," Journal of Money, Credit, and Banking, forthcoming, 1998.

Schumpeter, Joseph A. "The Theory of Economic Development", 1912, translated by Redvers Opie. Cambridge, MA: Harvard University Press, 1934.

Watson, Mark. "A Note on Estimating Deterministic Trends in the Presence of Serially Correlated Errors," 1992, Northwestern University Working Paper.

Williamson, Stephen D. "Financial Intermediation, Business Failures, and Real Business Cycles," Journal of Political Economy, December 1987, 95(6), pp. 135-45. 


\section{Data Appendix}

\section{A. Countries in the Sample}

1 in the 63 country cross-country sample for GDP, capital and productivity growth

2 in the 77 country panel sample for GDP, capital and productivity growth

3 in the 72 country panel sample for alternative productivity measures

$4 \quad$ in the 61 country cross-country sample for private saving

5 in the 72 country panel sample for private saving

\begin{tabular}{|c|c|c|}
\hline Algeria $(2,3)$ & Guatemala (1-5) & Nigeria $(4,5)$ \\
\hline Argentina $(1,2,3)$ & Guyana (1-3) & Norway (1-5) \\
\hline Australia (1-5) & Haiti (1-3) & Pakistan (1-5) \\
\hline Austria (1-5) & Honduras (1-5) & Panama (1-3) \\
\hline Bahamas (5) & Iceland $(4,5)$ & Papua New Guinea (1-5) \\
\hline Bangladesh $(4,5)$ & India $(1-5)$ & Paraguay (1-3) \\
\hline Belgium (1-5) & Indonesia $(2,4,5)$ & Peru $(1-4)$ \\
\hline Belize (5) & $\operatorname{Iran}(2,3)$ & Philippines (1-5) \\
\hline Bolivia (1-3) & Ireland (1-5) & Portugal (1-5) \\
\hline Brazil (1-3) & Israel (1-3) & Rwanda (2-5) \\
\hline Cameroon $(2,3,5)$ & Italy $(1-5)$ & Senegal (1-5) \\
\hline Canada $(1-5)$ & Jamaica $(1-5)$ & Sierra Leone (2-5) \\
\hline Central African Republic $(2,5)$ & Japan $(1-5)$ & South Africa (1-5) \\
\hline Chile (1-5) & Jordan (5) & Spain $(1-5)$ \\
\hline Colombia (1-5) & Kenya (1-5) & Sri Lanka (1-5) \\
\hline Congo $(2,3)$ & Korea (1-5) & Sudan $(2,3)$ \\
\hline Costa Rica (1-5) & Lesotho $(2,5)$ & Swaziland (5) \\
\hline Cote d"Ivoire (5) & Luxembourg (5) & Sweden (1-5) \\
\hline Cyprus (1-5) & Madagascar $(4,5)$ & Switzerland (1-5) \\
\hline Denmark $(1-5)$ & Malawi $(2,4,5)$ & Syria $(2-5)$ \\
\hline Dominican Republic (1-3) & Malaysia (1-5) & Taiwan (1) \\
\hline Ecuador (1-5) & Malta (1-4) & Thailand (1-5) \\
\hline Egypt (2-5) & Mauritius $(1,2,4,5)$ & Togo $(1-5)$ \\
\hline El Salvador $(1-3,5)$ & Mexico (1-4) & Trinidad and Tobago (1-5) \\
\hline Ethiopia (5) & Morocco (5) & United States of America (1-5) \\
\hline Finland (1-5) & Myanmar $(4,5)$ & Uruguay (1-4) \\
\hline France (1-5) & Nepal (5) & Venezuela (1-5) \\
\hline Gambia $(2-5)$ & Netherlands (1-5) & Zaire (1-3) \\
\hline Germany $(1-3,5)$ & New Zealand (1-5) & Zimbabwe $(1-3,5)$ \\
\hline Ghana (1-5) & Nicaragua $(2,3)$ & \\
\hline Great Britain (1-5) & Niger (1-5) & \\
\hline Greece $(1-5)$ & & \\
\hline
\end{tabular}




\section{B. Data Sources}

The first ten variables are from Loayza, Lopez, Schmidt-Hebbel, and Serven (1998). These numbers are revised and cross-checked National Account data.

1. Log level and growth rate of per capita GDP.

2. Log level and growth rate of per capita gross private disposable income (GPDI).

3. Private saving rates is the ratio of gross private savings and GPDI. Gross private saving is measured as the difference between gross national saving (gross national product minus consumption expenditure, both measured at current prices) and gross public saving. GPDI is measured likewise as the difference between gross national disposable income (GNDI) and gross public disposable income (sum of public saving and consumption).

4. Government size is real general government consumption as share of real GDP.

5. Openness to trade is the sum of real exports and real imports of goods and nonfinancial services as share of real GDP.

6. Government saving is the ratio of gross public saving and gross private disposable income.

7. Real interest rate is defined as $\ln [(1+i) / 1+p)]$, where $i$ is the nominal interest rate and $p$ the inflation rate. The inflation rate is the average of the current and year-ahead inflation.

8. Terms of Trade

9. Old and young dependency ratios are the shares of population under 15 and over 65 , respectively, in total population.

10. Urbanization ratio

11. Inflation rates are calculated using average annual CPI data from the International Financial Statistics (IFS), line 64.

12. The average years of secondary schooling in the total population (15 years and over) come from Barro and Lee (1996): They are for the initial year of the period

13. Data on the black market premium are from World's Currency Yearbook; and Adrian Wood, Global trends in real exchange rates: 1960-84, WB Discussion paper no. 35. 1988.

The numbers are averages over the 5-year periods.

14. Data on Private Credit are calculated using IFS numbers and the following method:

$$
\left\{(0.5) *\left[\mathrm{~F}(\mathrm{t}) / \mathrm{P} \_\mathrm{e}(\mathrm{t})+\mathrm{F}(\mathrm{t}-1) / \mathrm{P} \_\mathrm{e}(\mathrm{t}-1)\right]\right\} /\left[\mathrm{GDP}(\mathrm{t}) / \mathrm{P} \_\mathrm{a}(\mathrm{t})\right]
$$


where $\mathrm{F}$ is credit by deposit money banks and other financial institutions to the private sector (lines $22 \mathrm{~d}$ $+42 \mathrm{~d}$ ). If there are no data on 42d, we assume that the value is zero. GDP is line 99b, P_e is end-of period CPI (line 64) and P_a is the average annual CPI.

15. Data on Liquid Liabilities are calculated using IFS numbers and the following method:

$$
\left\{(0.5) *\left[\mathrm{~F}(\mathrm{t}) / \mathrm{P} \_\mathrm{e}(\mathrm{t})+\mathrm{F}(\mathrm{t}-1) / \mathrm{P} \_\mathrm{e}(\mathrm{t}-1)\right]\right\} /\left[\mathrm{GDP}(\mathrm{t}) / \mathrm{P} \_\mathrm{a}(\mathrm{t})\right]
$$

where $\mathrm{F}$ is liquid liabilities (line 551) or money plus quasi money (line 351), if liquid liabilities is not available. If neither liquid liabilities nor money plus quasi money are available, we use time and savings deposits (line 25). GDP is line 99b, P_e is end-of period CPI (line 64) and P_a is the average annual CPI. The numbers are averages over the 5 year periods.

16. Data on Commercial versus Central Bank are calculated using IFS numbers, using the following method:

$$
\mathrm{DBA}(\mathrm{t}) /(\operatorname{DBA}(\mathrm{t})+\mathrm{CBA}(\mathrm{t}))
$$

where DBA is assets of deposit money banks (lines 22a-d) and CBA is central bank assets (lines 12 ad). 
Table 1: Summary Statistics: 1960-1995

\section{Descriptive Statistics}

\begin{tabular}{|c|c|c|c|c|c|c|c|}
\hline & $\begin{array}{l}\text { Private } \\
\text { Credit }\end{array}$ & $\begin{array}{l}\text { Economic } \\
\text { Growth }\end{array}$ & $\begin{array}{l}\text { Capital } \\
\text { Growth }\end{array}$ & $\begin{array}{c}\text { Productivity } \\
\text { Growth } 1\end{array}$ & $\begin{array}{c}\text { Productivity } \\
\text { Growth } 2\end{array}$ & $\begin{array}{c}\text { Productivity } \\
\text { Growth } 3\end{array}$ & $\begin{array}{l}\text { Private } \\
\text { Saving }\end{array}$ \\
\hline Mean & 40.15 & 1.95 & 3.13 & 1.01 & 0.13 & 0.74 & 19.21 \\
\hline Median & 27.51 & 1.98 & 3.11 & 1.15 & 0.44 & 0.99 & 19.98 \\
\hline Maximum & 141.29 & 7.16 & 10.51 & 5.14 & 4.87 & 7.01 & 33.91 \\
\hline Minimum & 4.08 & -2.81 & -1.84 & -3.39 & -5.74 & -5.59 & 1.05 \\
\hline Std. Dev. & 29.16 & 1.92 & 2.22 & 1.52 & 1.82 & 2.11 & 7.65 \\
\hline \multirow[t]{3}{*}{ Observations } & 63 & 63 & 63 & 63 & 63 & 63 & 61 \\
\hline & & Correlations & & & & & \\
\hline & $\begin{array}{l}\text { Private } \\
\text { Credit }\end{array}$ & $\begin{array}{l}\text { Economic } \\
\text { Growth }\end{array}$ & $\begin{array}{l}\text { Capital } \\
\text { Growth }\end{array}$ & $\begin{array}{c}\text { Productivity } \\
\text { Growth } 1\end{array}$ & $\begin{array}{c}\text { Productivity } \\
\text { Growth } 2\end{array}$ & $\begin{array}{c}\text { Productivity } \\
\text { Growth } 3\end{array}$ & \\
\hline
\end{tabular}

\section{Private Credit}

Economic Growth

Capital Growth

Productivity Growth 1

Productivity Growth 2

Productivity Growth 3

Private Saving

$\mathrm{p}$-values are reported in parentheses
1.00

0.43 (0.001)

0.34

(0.006)

0.39

(0.002)

0.44
$(0.001)$

$0.001)$

0.38
$(0.002)$

0.74

(0.001)
1.00

0.71

(0.001)

0.95

(0.001)

0.87

(0.001)

0.92

(0.001)

Growth

Growth 1

1.00

0.46

(0.001)

0.36
$(0.004)$

(0.004)

0.39

(0.002)

1.00

0.94

(0.001)

$0.99 \quad 0.96$

(0.001)

0.96

(0.001)

Productivity Growth 1 = output per capita growth $-0.3^{*}$ capital per capita growth

Productivity Growth 2 = output per capita growth $-0.3^{*}$ capital per capita growth -0.5 * growth in average years of schooling

Productivity Growth $3=$ [output per capita growth $-0.3{ }^{*}$ capital per capita growth $-0.7{ }^{*}$ change in (average years of schooling * return on schooling)] $/ 0.7$

Statistics for national saving and its correlation with measures of financial development are from a different sample 